\title{
Pengendalian Tikus Sawah (Rattus Argentiventer) dengan Sistem Bubu Perangkap dan Perangkap Bambu Pada 3 Zona Habitat Tikus di Kabupaten Pinrang Kota Makassar
}

\author{
Muslimin Sepe ${ }^{1}$, Suhardi $^{2}$ \\ ${ }^{1}$ Jurusan Agroteknologi, Fakultas Pertanian, Universitas Ichsan Gorontalo Jl. Raden Saleh No. 17. Kota Gorontalo. \\ ${ }^{2}$ Jurusan Agroteknologi, Fakultas Sains dan Teknologi, Universitas Muhammadiyah Enrekang. Jl. Jenderal Sudirman, Galonta, Kec. \\ Enrekang, Kabupaten Enrekang, Sulawesi Selatan 91711.
}

Email : $\underline{\text { musliminsepe@gmail.com }}$

\begin{abstract}
Tikus sawah (Rattus argentiventer) merupakan hama utama penyebab kerusakan dan kehilangan hasil tanaman padi di Indonesia. Penelitian ini bertujuan untuk mengetahui efektivitas perangkap sistem bubu linier dan perangkap bambu untuk mengendalikan tikus yang dipasang pada 3 zona habitat yang berbeda. Pengendalian hama tikus dengan sistem perangkap bubu linier dan perangkap bambu dilakukan di Kecamatan Mattiro Sompe, Kabupaten Pinrang. Percobaan dilaksanakann dalam bentuk percobaan faktorial yang disusun dalam RAK dengan tiga perlakuan. Pengambilan data dilakukan pada tiga zona habitat tikus yaitu pada daerah sekitar perkampungan, perkebunan, dan daerah sekitar tanggul irigasi. Semua zona tikus ini berbatasan dengan sawah. Perlakuan terdiri dari atas perangkap bubu linier, Perangkap bambu, dan kontrol yakni petak sawah tanpa pemasangan perangkap. Setiap perangkap perlakuan diulang dua kali. Perangkap bubu linier terdiri atas pagar plastik, tinggi $50 \mathrm{~cm}$ dan panjang $600 \mathrm{~m}$, dipasang mengelilingi petak-petak sawah sebagai unit percobaan. Bubu terbuat dari ram kawat berukuran 25 x $25 \times 60 \mathrm{~cm}$. Pemasangan bubu dilakukan setiap jarak $20 \mathrm{~m}$, dalam penelitian ini dipasang 72 buah bubu. Berdasarkan zona tangkapan rata-rata populasi tikus yang terperangkap tertinggi terdapat pada zona irigasi yaitu 23.75 ekor. Berdasarkan zona tangkapan rata-rata intensitas serangan tertinggi terdapat pada zona perkampungan yaitu 6.39\%. Berdasarkan zona tangkapan rata-rata produksi tertinggi terdapat pada zona irigasi yaitu 11.07 ton/ha.
\end{abstract}

Keywords: TBS, Perangkap Bambu, Padi, Tikus

\section{PENDAHULUAN}

Padi (Oryza sativa L.) merupakan tanaman penting bagi penduduk Indonesia, selain itu, padi juga sebagai sumber karbohidrat bagi setengah dari populasi penduduk dunia (IRRI 1989). Produksi beras memainkan peran penting dalam pembangunan ekonomi di beberapa negara. Menurunkan produksi komoditas beras dapat berdampak buruk terhadap negara-negara penghasil beras. Masalah yang dihadapi oleh semua negara penghasil beras di dunia adalah hama serangga dan penyakit tanaman yang dianggap sebagai faktor utama dalam berkontribusi terhadap penurunan produksi padi (Fahad et al. 2015).

Kendala dalam pencapaian produksi padi yaitu adanya serangan oleh organisme pengganggu tumbuhan (OPT) dan damfak fenomena iklim (DFI) (Syam dan Wurjandari, 2005; Khamid et al., 2019). Beberapa hama yang berpotensi merusak pertanaman padi adalah tikus, penggerek batang padi, wereng coklat, wereng hijau, dan walang sangit (Effendi, 2009). Rata-rata kehilangan hasil produksi pertanian karena serangan OPT $\pm 30 \%$ dari potensi hasil, dan kehilangan hasil karena hama sekitar 2025\% (Usyati et al., 2018)

Tikus sawah (Rattus argentiventer) merupakan hama utama yang dapat menimbulkan kerusakan besar pada semua stadium pertumbuhan padi mulai dari persemaian hingga panen, bahkan di gudang penyimpanan. Kerusakan berat dapat terjadi jika tikus menyerang padi pada stadium generatif. Hal ini disebabkan karena tanaman padi tidak mampu lagi membentuk anakan baru. Kerusakan oleh tikus pada pertanaman padi dimulai dari tengah petak, kemudian meluas ke arah pinggir, dan menyisakan 1-2 baris padi di pinggir petakan pada keadaan serangan berat.

Tikus aktif menyerang tanaman padi pada malam hari, sedangkan pada siang hari bersembunyi di dalam lubang pada tanggul-tanggul irigasi, jalan sawah, pematang, dan daerah perkambungan. Periode sawah bera, sebagian besar tikus bermigrasi ke daerah perkampungan dekat sawah dan akan kembali lagi ke sawah setelah pertanaman padi menjelang fase generatif.

Tikus sawah termasuk hama yang relatif sulit dikendalikan. Hal ini disebabkan karena perkembangan dan mobilitas tikus yang cepat serta daya rusak pada pertanaman padi yang cukup tinggi. Hama tikus selalu menjadi ancaman pada pertanaman padi yang dapat menyebabkan kehilangan hasil yang cukup besar. karena menyerang tanaman padi di persemaian hingga menjelang panen (Bakar dan Azis. 2008).

Aktivitas harian tikus berkaitan dengan kebutuahn untuk mencari pakan dan berkembang biak. Tikus cenderung memilih atau tertarik tanaman padi stadia yang lebih tua. Tristiana et al. (1992) mengemukakan bahwa rata-rata rumpun padi yang terpotong oleh seekor tikus 
meningkat mulai saat primodia (7.1 rumpun per malam), stadia bunting (11.9 rumpun per malam), dan stadia kuluar malai (13.2 rumpun per malam). Apabila kondisi di lapangan (sawah) terdapat pertanaman terlambat panen, maka tanaman tersebut akan diserang tikus.

Pola serangan tikus ini dapat dimanfaatkan sebagai dasar pengendalian tikus dengan menggunakan berbagai teknik secara terpadu yakni, pemanfaatan teknologi pengendalian yang berwawasan lingkungan seperti pengendalian dengan Sistem Bubu Linier, yang sistem pengendaliannya dapat menangkap tikus migran yang berasal dari sekitar persawahan. Sistem pengendalian tersebut akan dikombinasikan dengan pengendalian secara mekanik dengan pemanfaatan perangkap bambu yang dapat menangkap tikus dalam jumlah yang banyak. Tujuan dari penelitian ini untuk mengetahui efektivitas perangkap sistem bubu perangkap dan perangkap bambu untuk mengendalikan tikus yang dipasang pada tiga zona habitat yang berbeda. Kegunaan adalah sebagai bahan informasi bagi petani dalam usaha mengendalikan hama tikus yang tidak merusak lingkungan.

\section{BAHAN DAN METODE}

\section{Tempat dan Waktu}

Penelitian berbentuk percobaan lapang yang dilakukan di Desa Langnga, Kecamatan Mattiro Sompe, Kabupaten Pinrang, Kota Makassar. Pemilihan lokasi ini dilakukan dengan pertimbangan bahwa Desa Langnga, Kecamatan Mattiro Sompe merupakan salah satu daerah sentra pertanaman padi di Kabupaten Pinrang. Pelaksanaan penelitian dilaksanakan selama 5 bulan.

\section{Metode Pelaksanaan}

Penelitian pengendalian tikus dengan Sistem Bubu Perangkap (TBS) di tempatkan di lahan sawah yang ditanami padi dengan jarak tanam 25 x $25 \mathrm{~cm}$, padi varietas Swambada, pada umur padi \pm 14 HST.

Perlakuan yang di cobakan sebagi berikut:

1. $\mathrm{TBS}=$ Plastik + Bubu

2. Perangkap Bambu= Bambu+Sekam Padi

3. Kontrol $=$ Tanpa Perlakuan

Percobaan dilaksanakan dalam percobaan faktorial yang disusun dalam RAK dengan tiga perlakuan masingmasing dengan dua ulangan di lanjutkan dengan Uji BNT.

Sistem Bubu Perangkap merupakan sistem pengendalian yang dapat menangkap tikus migran dari sekitar persawahan, dibuat dengan menggunanakan pagar plastik setinggi $50 \mathrm{~cm}$, panjang $100 \mathrm{~m}$ yang ditegakkan dengan ajir bambu pada setiap jarak $1 \mathrm{~m}$. Bubu perangkap yang berukuran $(25 \times 60) \mathrm{cm}$ dipasang pada setiap sisi di dalam pagar plastik dengan lubang menghadap keluar.

Bagian luar pagar plastik dibuatkan parit sedalam 0.25 $\mathrm{m}$. Bagian bawah pagar digenangi air, sehingga tikus dapat melubangi plastik atau menggali lubang di bawah perangkap. Jarak TBS satu dengan yang lain berjarak \pm $250 \mathrm{~m}$.

Pemasangan perangkap bubu dilakukan dengan jarak $20 \mathrm{~m}$ sehingga setiap perangkap dipasang 8 bubu pada tiap ulangan perlakuan. Pemasangan ini dilakukan di 3 zona habitat tikus yaitu sekitar batas perkampungan, tanggul irigasi, dan sekitar perkebunan. Setiap hari perangkap bubu diamati kemudian tikus yang tertangkap dimatikan dengan cara ditenggalamkan di parit.

Perangkap bambu merupakan perangkap yang terbuat dari bambu dengan panjang 1-1.5 m, pemasangan perangkap bambu dilakukan di pematang sawah. Pemasangan perangkap bubu dilakukan dengan jarak $15 \mathrm{~m}$ sehingga setiap perangkap dipasang 6 bambu pada tiap ulangan perlakuan. Pemasangan ini dilakukan di 3 zona habitat tikus yaitu sekitar batas perkampungan, tanggul irigasi, dan sekitar perkebunan. Pengamatan dilakukan tiap hari.

\section{Parameter pengamatan}

Pengamatan dilakukan mulai 14 HST (Hari setelah tanam) sampai panen, dengan parameter pengamatan adalah: 1) Populasi tikus terperangkap pada Perangkap Bubu Linier di amati tiap hari, 2) Populasi tikus tertangkap pada perangkap bambu yang diamati tiap hari, 3) Persentase serangan tikus pada lahan pemasangan perangkap bubu, perangkap bambu, dan lahan kontrol, dan 4) Produksi padi pada tiap-tiap perlakuan dan zona pengamatan. Pengamatan intensitas serangan tikus dilakukan dengan mengambil contoh sampel $1 \mathrm{~m}^{2}$, dengan cara berjalan dari sudut petakan sawah ke sudut yang lain, kemudian setiap sepuluh langkah diamati rumpun yang terserang.

Penentuan intensitas serangan tikus dihitung dengan rumus (Priyambodo 2006):

$$
I=\frac{a}{a+b} \times 100 \%
$$

Keterangan :

$$
\begin{array}{ll}
\mathrm{I} & =\text { Intensitas serangan }(\%) \\
\mathrm{A} & =\text { Jumlah anakan yang terserang } \\
\mathrm{B} & =\text { Jumlah anakan yang tidak terserang }
\end{array}
$$

\section{HASIL DAN PEMBAHASAN}

\section{Populasi Tikus Sawah}

Hasil penelitian menunjukkan bahwa jumlah tikus yang terperangkap pada tiap perlakuan selama pengamatan bervariasi pada tiap zona tangkapan tempat pemasangan perangkap. Analisis ragam terhadap jumlah tangkapan tikus menunjukkan bahwa perlakuan perangkap yang dipasang sangat berpengaruh nyata, sedangkan jumlah 
tikus yang terperangkap dalam tiga zona pengamatan berbeda nyata (Tabel 1).

Tabel 1. Rata-rata tikus terperangkap (ekor) pada tiga zona tangkapan dengan berbagai macam perangkap perlakuan.

\begin{tabular}{lcccc}
\hline Perangkap & \multicolumn{3}{c}{ Rata-rata } & Rata- \\
\cline { 2 - 4 } & Perkampungan & Perkebunan & Irigasi & rata \\
\hline TBS & $38.0 \mathrm{~b}$ & $29.0 \mathrm{~b}$ & $45.5 \mathrm{a}$ & 47.5 \\
Perangkap Bambu & $1.5 \mathrm{c}$ & $4.0 \mathrm{c}$ & $2.0 \mathrm{c}$ & 2.5 \\
Rata-rata & 19.75 & 16.5 & 23.75 & 20 \\
\hline Keterangan & $\begin{array}{l}\text { : Angka-angka yang diikuti oleh huruf yang sama pada } \\
\text { kolom yang sama tidak berbeda nyata pada taraf } 0,05\end{array}$ \\
& $\begin{array}{l}\text { dengan uji BNT } \\
\end{array}$
\end{tabular}

Rata-rata jumlah tikus yang terperangkap pada perangkap bubu linier TBS lebih banyak yaitu 37.5 ekor dan berbeda nyata dengan jumlah tikus yang terperangkap pada perangkap jala yaitu 2.5 ekor. Jumlah tikus yang terperangkap pada masing-masing cara pengendalian, selain dipengaruhi efektivitas perangkap tersebut, juga bergantung pada teknik penerapan perangkap dalam melakukan pengendalian tikus. Walaupun cara pengendalian tikus yang paling efektif adalah sistem TBS, namun penerapan perlu dikombinasikan dengan cara-cara pengendalian lainnya.

Tikus terperangkap merupakan tikus-tikus yang bermigasi dari ketiga zona yang dipilih sebagai unit percobaan. Tabel 1 menunjukkan bahwa rata-rata tikus yang terperangkap pada zona irigasi lebih banyak yaitu 23.75 ekor tetapi tidak berbeda nyata dengan jumlah tikus yang terperangkap pada zona perkampungan yaitu 19.75 ekor. Rata-rata tikus yang terperangkap pada zona perkebunan merupakan jumlah yang terendah yaitu 16.5 ekor tetapi tidak berbeda nyata pada zona perkampungan dengan jumlah tikus yang terperangkap.

Banyaknya jumlah tikus yang terperangkap pada zona irigasi disebabkan karena lahan persawahan berada pada zona irigasi yang berbatasan dengan semak belukar, dimana tikus banyak berlindung dari gangguan predator dan tersedianya cukup makanan dan air disekitarnya. Tikus menghindari lingkungan yang tidak menguntungkan, dengan cara membuat sarang pada daerah lembab, dekat dengan sumber air dan makanan seperti di batang pohon, sela-sela batu, tanggul-tanggul irigasi, dan bukit-bukit kecil (Muliyadi 2009; Sudarmaji dan Anggara 2006).

Tikus yang terperangkap pada zona perkebunan berasal dari kebun kelapa dan tanaman jagung, berpindah ke sawah saat tanaman padi sudah mulai membentuk malai. Priyambodo (1995) mengungkapkan bahwa pada periode sawah bera, sebagian besar tikus bermigrasi ke daerah perkampungan dekat sawah dan akan kembali lagi ke sawah setelah pertanaman padi menjelang fase generatif. Pada zona perkampungan jumlah tikus yang terperangkap lebih rendah dibanding zona irigasi karena pada zona tersebut tikus banyak mengalami gangguan akibat lokasi yang sangat dekat dengan perumahan penduduk di samping pada zona tersebut banyak dijumpai predator yaitu ular dan biawak.Analisis ragam gabungan antara zona tangkapan terhadap jumlah tikus yang terperangkap masing-masing dengan dua perangkap perlakuan menunjukkan interaksi yang nyata. Jumlah tikus yang terperangkap pada zona irigasi dengan menggunakan TBS lebih banyak yaitu 45.5 ekor dibandingkan dengan jumlah tikus yang terperangkap pada zona perkampungan dan zona perkebunan dengan menggunakan perangkap yang sama yaitu masing-masing 38.0 ekor dan 29.0 ekor.

Uji lanjut dengan BNT taraf $0.5 \%$ menunjukkan bahwa jumlah tikus yang terperangkap pada zona irigasi berbeda nyata dengan zona perkampungan dan zona perkebunan. Akan tetapi jumlah tikus yang terperangkap pada zona perkampungan dan zona perkebunan tidak berbeda nyata (Tabel 1). Jumlah tikus yang terperangkap pada zona perkebunan dengan menggunakan perangkap bambu lebih banyak yaitu 4.0 ekor dibandingkan jumlah tikus yang terperangkap pada zona terperangkap 2.0 ekor dan zona perkampungan yaitu 1.5 ekor. Jumlah tikus yang terperangkap pada ke tiga zona dengan menggunakan perangkap bambu menunjukatan tankapan yang tergolon sedikit dan tidak berbeda nyata (Gambar 1).
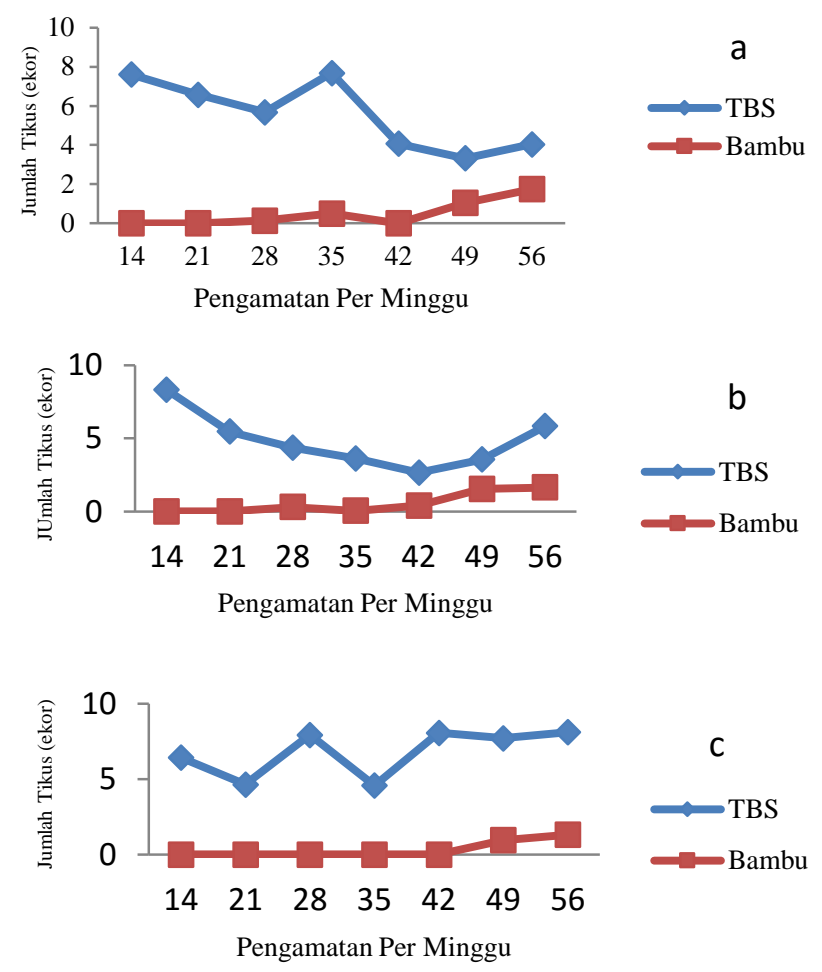

Gambar 1. Jumlah rata-rata tangkapan tikus (ekor) pada masing-masing zona: a) Perkampungan, b) Perkebunan, dan c) Irigasi

Gambar 1 menunjukkan bahwa tikus sudah mulai terdapat di pertanaman pada umur kurang lebih 21-28 HST sampai umur tanaman \pm 56 HST dengan jumlah tikus yang 
terperangkap berkisar antara 0-8 ekor hari. Populasi tikus tertinggi pada semua zona tangkapan mulai terdapat pada umur 21-56 HST yakni waktu tanaman padi mulai bunting sampai terbentuk malai. Tampak pula bahwa semua zona percobaan jumlah tikus yang terperangkap menunjukkan tiga pola variasi yakni pada minggu-minggu awal tangkapan relatif agak tinggi kemudian berfluaktuasi dan menurun pada masing-masing selanjutnya. IRRI (1989) mengemukakan bahwa tikus makan tanaman padi pada berbagai fase pertumbuhan tetapi kerusakan paling besar terjadi setelah pembentukan bakal malai.

\section{Intensitas Serangan Tikus Sawah}

Rata-rata intensitas serangan tikus sawah (R. argentiventer) bervariasi berdasarkan jenis perlakuan perangkap pada tiga zona tangkapan tikus. Intensitas serangan pada tiga zona tangkapan menunjukkan bahwa pada perlakuan TBS tidak menunjukkan serangan (Tabel 2).

Tabel 2. Rata-rata intensitas serangan (\%) tiap zona tangkapan tikus dengan berbagai macam perangkap perlakuan.

\begin{tabular}{lcll}
\hline Perangkap & \multicolumn{3}{c}{ Rata-rata } \\
\cline { 2 - 4 } & Perkampungan & Perkebunan & Irigasi \\
\hline TBS & $0.00 \mathrm{f}$ & $0.00 \mathrm{f}$ & $0.00 \mathrm{f}$ \\
Perangkap & $8.30 \mathrm{c}$ & $7.66 \mathrm{~d}$ & $7.37 \mathrm{e}$ \\
Bambu & & & \\
Kontrol & $10.88 \mathrm{a}$ & $8.26 \mathrm{c}$ & $9.29 \mathrm{~b}$ \\
Rata-rata & 6.39 & 5.31 & 5.55 \\
\hline Ketrangan:
\end{tabular}

Keterangan: Angka-angka yang diikuti oleh huruf yang sama pada kolom yang sama tidak berbeda nyata pada taraf 0.05 dengan uji BNT.

Tabel 2. Menunjukkan bahwa intensitas serangan tikus pada semua pengamatan berkisar antara 0.00-10.88\%. Rata-rata intensitas serangan tertinggi terdapat pada zona perkampungan yaitu $6.39 \%$, menyusul pada zona irigasi yaitu $5.55 \%$. Intensitas serangan terendah terdapat pada zona perkebunan yaitu $5.31 \%$. Terlihat pula bahwa serangan tikus hanya dijumpai pada petak yang dipasangi perangkap jala dan pada lahan kontrol (petak yang tidak dipasangi perangkap). Intensitas kerusakan tertinggi dijumpai pada zona perkampungan yakni pada petak yang tidak dipasangi perangkap (kontrol) yaitu $10.88 \%$.

Terjadinya tingkat serangan yang tertinggi pada zona perkampungan disebabkan karena kebanyakan tikus melakukan migrasi ke daerah pemukiman warga setelah terjadi penggenangan air pada zonapersawahan pada umur padi 28-35 HST sehingga menyebabkan tingkat populasi dan aktivitas hidup tikus meningkat di daerah perkampungan.

Intensitas serangan pada zona irigasi lebih rendah jika dibandingkan dengan zona perkampungan dipengaruhi oleh beberapa faktor: 1) terdapatnya sumber makanan yang melimpah menyebabkan aktifitas makan tikus sawah juga terbagi-bagi disetiap pertanaman padi di zona irigasi, 2) aktivitas petani yang tinggi di daerah irigasi menyebabkan tikus-tikus lebih cenderung untuk mencari sumber makanan yang cukup aman dari gangguan petani, dan 3) Partisipasi petani yang cukup merespon tentang pengendalian tikus menyebabkan intensitas serangan berkurang dari sebelumnya di zona irigasi (Gambar 2).
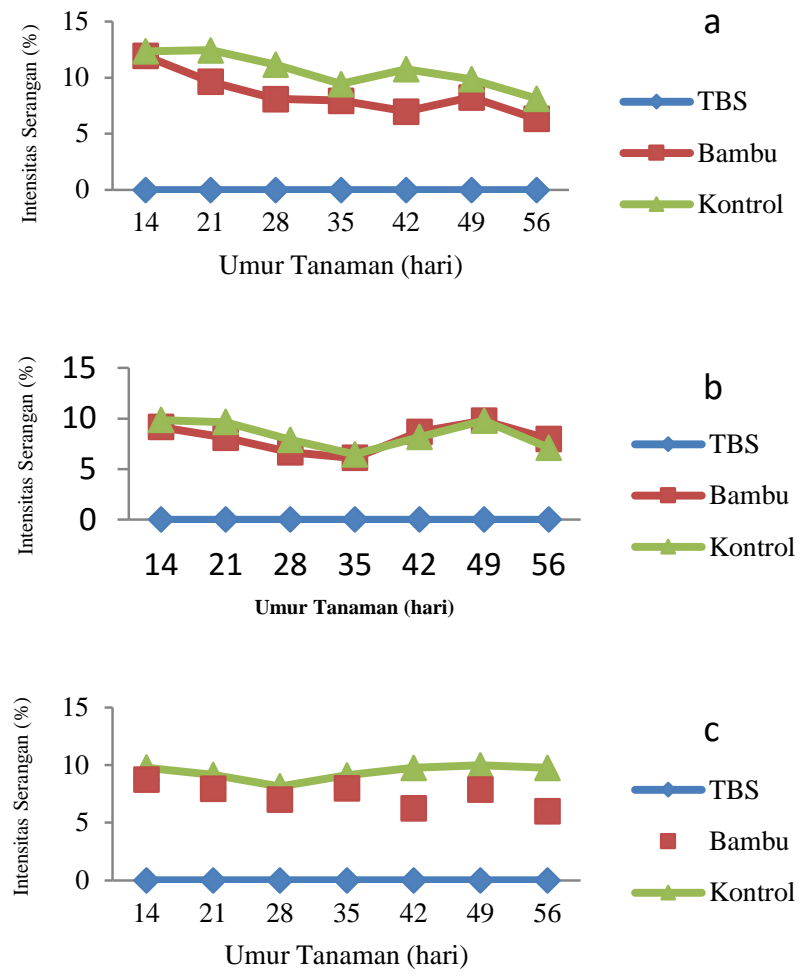

Gambar 2. Rata-rata intensitas serangan tikus sawah (\%) pada masing-masing zona tangakapan: a) Perkampunga, b) Perkebunan, dan c) Irigasi.

Gambar 2 menunjukkan bahwa rata-rata intensitas serangan tikus pada zona perkampungan dengan perlakuan perangkap bambu berkisar antara 6.49-11.38\% selama 56 hari pengamatan. Hasil pengamtan intensitas serangan tertinggi pada perlakuan bambu yaitu $11.38 \%$ pada pengamatan hari ke 14 dan terendah pada hari ke 56 yaitu $6.49 \%$.

Pada lahan kontrol rata-rata intensitas serangan tikus berkisar antara 8.96-12.91\%. Hasil pengamatan tertinggi terjadi pada pengamtan hari ke 14 dan terendah pada pengamatan hari ke 56. Sedangkan pada perangkap TBS tidak memperlihatkan serangan tikus.

Pada zona perkebunan memperlihatkan bahwa intensitas serangan berkisar antara $6.61-8.86 \%$ pada lahan yang dipasangi perangkap bambu, intensitas serangan tertinggi terjadi pada pengamatan hari ke 42. Sedangkan pada lahan kontrol intensitas serangan berkisar antara 6.60-9.60\%, intensitas serangan tertinggi terjadi pada pengamatan hari ke 14 dan terendah terjadi pada 
pengamatan hari ke 35 . Berdasarkan perangkap TBS tidak didapatkan hasil serangan tikus.

Zona irigasi memperlihatkan intensitas serangan yang berkisar antara $6.00-9.13 \%$ selama pengamatan berlangsung dengan menggunakan parangkap bambu yang dipasang satu kali dalam seminggu. Intensitas serangan tertinggi terjadi pada pengamatan ke 14 dan terendah terjadi pada pengamatan hari ke-56. Pada lahan kontrol memperlihatkan intensitas serangan tertinggi terjadi pada pengamatan hari ke 49 yaitu $9.85 \%$ dan terendah terjadi pada pengamatan hari ke 28 yaitu $8.49 \%$.

\section{Hasil Produksi Berat Gabah Kering Panen Tanaman Padi (ton/ha)}

Rata-rata produksi berat gabah kering panen pada tiga zona tangkapan tikus dengan menggunakan berbagai macam perangkap menghasilkan berat biji yang variatif. Hasil produksi berat gabah kering panen tertinggi pada zona irigasi (Tabel 3).

Tabel 3. Rata-rata hasil produksi berat gabah kering panen (ton/ha) tanaman padi pada tiga zona tangakapan tikus.

\begin{tabular}{llcl}
\hline Perangkap & \multicolumn{3}{c}{ Rata-rata } \\
\cline { 2 - 4 } & Perkampungan & Perkebunan & Irigasi \\
\hline TBS & $11.28 \mathrm{a}$ & $12.04 \mathrm{a}$ & $12.57 \mathrm{a}$ \\
Jala & $10.36 \mathrm{a}$ & $10.11 \mathrm{a}$ & $10.49 \mathrm{a}$ \\
Kontrol & $9.70 \mathrm{a}$ & $9.78 \mathrm{a}$ & $10.16 \mathrm{a}$ \\
\hline Rata-rata & 10.45 & 10.64 & 11.07 \\
\hline
\end{tabular}

Keterangan : Angka-angka yang diikuti oleh huruf yang sama pada kolom yang sama tidak berbeda nyata pada taraf 0,05 dengan uji BNT.

Tabel 3. Menunjukkan bahwa rata-rata hasil produksi pada masing-masing perlakuan perangkap berkisar antara $9.70-12.57$ (ton/ha). Hasil produksi tertinggi terdapat pada zona irigasi 11.07 (ton/ha), menyusul zona perkebunan 10.64 (ton/ha), dan terendah terjadi pada zona perkampungan 10.45 (ton/ha).

Analisis ragam gabungan produksi berat gabah kering tanaman padi menurut jenis perangkap pada uji BNT $1 \%$ menunjukkan bahwa perlakuan TBS memperlihatkan rata-rata produksi berat biji yang paling tinggi (11.96 ton/ha) tidak berbeda nyata dengan dua perlakuan lainnya.

Produksi berat gabah kering pada tig zona tangkapan tersebut terbilang tinggi dari pada biasanya karena perlakuan petani terhadap pertanaman mereka cukup baik seperti pemupukan yaitu penggunaan pupuk urea $3 \mathrm{kw} / \mathrm{ha}$, pupuk SP $1 \mathrm{kw} / \mathrm{ha}$, Empoaska $1 \mathrm{Kw} / \mathrm{ha}$, dan hormon FMC $100 \mathrm{ml} / \mathrm{ha}$ yang dilakukan 2 kali saat padi masa bunting (vegetatif) dalam satu minggu (Hasil diskusi dengan beberapa kelompok tani padatiga zona tangakapan tikus). Sedangkan dalam pengendalian OPT mereka menggunakan bahan kimiawi seperti fungisida yang dikombinasikan dengan perlakuan perangkap pada penelitian yaitu TBS dan bambu, yang mampuh menekan sekecil mungkin populasi hama tikus di pertanaman padi.

\section{KESIMPULAN DAN SARAN}

Jumlah rata-rata tikus yang tertangkap pada perlakuan TBS lebih banyak dari jumlah rata-rata tikus yang tertangkap pada perangkap bambu. Berdasarkan zona tangkapan rata-rata populasi tikus yang terperangkap tertinggi terdapat pada zona irigasi yaitu 23.75 ekor.

Jumlah rata-rata intensitas serangan tikus tertinnggi terdapat pada lahan kontrol. Hal ini terjadi karena tidak adanya penghalang fisik untuk melakukan pengrusakan pada tanamn. Berdasarkan zona tangkapan rata-rata intensitas serangan tertinggi terdapat pada zona perkampungan yaitu $6.39 \%$.

Rata-rata hasil produksi tertinggi terdapat pada perlakuan TBS yitu 11.96 ton/ha, jika dibandingkan pada perlakuan jala dan lahan kontrol. Berdasarkan zona tangkapan rata-rata produksi tertinggi terdapat pada zona irigasi yaitu 11.07 ton/ha.

\section{DAFTAR PUSTAKA}

Baco D. 2011. Pengendalian Tikus Pada Tanaman Padi Melalui Pendekatan Ekologi. Balai Pengkajian Teknologi Pertanian Sulawesi Selatan. Makassar. Jurnal Pengembangan inovasi pertanian. 4 (I). hal 47-60

Basri A. Bakar dan Abdul Azis1. Prefalensi Tikus Sawah (Rattus argentiventer) terhadap jenis dan bentuk umpan pada Lokasi Prima Tani di Provinsi Aceh. Peneliti Balai Pengkajian Teknologi Pertanian Aceh. Halaman. 1-5.

Effendi, BS. 2009. Strategi pengendalian hama terpadu tanaman padi dalam perspektif praktek pertanian yang baik. Jurnal Pengembangan Inovasi. Vol. 2(1): 65-78.

Fahad S, Hussain S, Nie L, and Khan F. 2015. Rice Pest Management and Biological Control. Sustainable Agriculture Reviews. Sustainable Agriculture Reviews. Hal. 85-106.

Khamid MBR, Junaedi A, Lubis I, dan Yamamoto Y. 2019. Respon Pertumbuhan dan Hasil Padi (Oryza sativa L.) terhadap Cekaman Suhu Tinggi. J. Agron. Indonesia, Agustus 2019, 47(2):119-12.

IRRI 1989. IRRI towards 2000 and beyond. International Rice Research Institute Philippines. Los Banos. p 68.

Makarim M, Widiarta AIN, Hendarsih, Abdulrachman SS. 2003. Panduan teknis pengelolaan hara dan pengendalian hama penyakit tanaman secara terpadu. Dapertemen Pertanian. Hal: 21-25.

Priyambodo S. 2006. Pengendalian Hama Tikus Terpadu. Penebar Swadaya. Bogor (ID). Hal:5-28.

Solikhin, Purnomo. 2008. Preferensi Tikus Sawah (Rattus-rattus argentiventer) dan Pengaruhnya Terhadap Pola Kerusakan Padi Varietas Dodokan dan Cianjur. JHPT Tropika. Vol. 8, No. 1:23-30.

Sudarmaji dan Anggara AW. 2006. Pengendalian Tikus Sawah dengan Sistem Bubu Perangkap di Ekosistem Sawah Irigasi. Penelitian Pertanian Tanaman Pangan. Vol.25. no.1 Hal:57-65.

Usyati N, Kurniawati N, Ruskandar A, dan Rumasa O. 2018. Populasi Hama dan Musuh Alami pada Tiga Cara Budidaya Padi Sawah di Sukamandi. Jurnal Agrikultura. 2018, 29 (1): 35-42. 